\title{
Decrease of the DXR-induced genotoxicity and nongenotoxic effects of Theobroma cacao revealed by micronucleus assay
}

\author{
M. F. G. Boriollo ${ }^{a, b, c *}$ (D), V. E. Alves ${ }^{b}$ (D), T. A. Silva $a^{b, c}$ (D), J. J. Silva ${ }^{a}$ (D), G. B. S. Barros ${ }^{b}$ (D), \\ C. T. S. Dias ${ }^{d}$ (D), J. F. Höfling ${ }^{a}$ (D) and N. M. S. Oliveira ${ }^{b, c}$
}

a'Laboratório de Genética Molecular, Departamento de Diagnóstico Oral, Faculdade de Odontologia de Piracicaba - FOP, Universidade Estadual de Campinas - UNICAMP, Av. Limeira, 901, Bairro Areião, CEP 13414-903, Piracicaba, SP, Brasil

${ }^{\text {b} L a b o r a t o ́ r i o ~ d e ~ F a r m a c o g e n e ́ t i c a ~ e ~ B i o l o g i a ~ M o l e c u l a r, ~ F a c u l d a d e ~ d e ~ C i e ̂ n c i a s ~ M e ́ d i c a s, ~ U n i v e r s i d a d e ~ J o s e ́ ~ d o ~ R o s a ́ r i o ~}$ Vellano - UNIFENAS, Rodovia MG 179, Km 0, Campus Universitário, CEP 37132-440, Alfenas, MG, Brasil

${ }^{c}$ Centro de Pesquisa e Pós-graduação em Ciência Animal, Área de Patologia e Farmacologia Animal, Universidade José do Rosário Vellano - UNIFENAS, Rodovia MG 179, Km 0, Campus Universitário, CEP 37132-440, Alfenas, MG, Brasil

'Departamento de Ciências Exatas, Escola de Agricultura "Luiz de Queiroz" - ESALQ, Universidade de são Paulo - USP, Av. Pádua Dias, 11, CEP 13418-900, Piracicaba, SP, Brasil

*e-mail: marcelo.boriollo@gmail.com

Received: May 7, 2019 - Accepted: November 4, 2019 - Distributed: May 31, 2021

(With 1 figure)

\begin{abstract}
This study evaluated the genotoxicity of lyophilized glycolic extract of Theobroma cacao Linné seeds (TCL), using the micronucleus assay in bone marrow of mice. The interaction between TCL and doxorubicin (DXR) was also analyzed. Experimental groups were evaluated 24-48 h after treatment with N-Nitroso-N-ethylurea (NEU: $50 \mathrm{mg} / \mathrm{kg}$ ), DXR ( $5 \mathrm{mg} / \mathrm{kg}), \mathrm{NaCl}(145 \mathrm{mM}), \mathrm{TCL}(0.5-2 \mathrm{~g} / \mathrm{kg})$, and TCL $(2 \mathrm{~g} / \mathrm{kg})$ in combination with DXR (antigenotoxic assays). Analysis of micronucleated polychromatic erythrocytes (MNPCEs) showed no significant differences between all the treatment doses of TCL and $\mathrm{NaCl}$ control. Mice experimentally treated with DXR and NEU significantly induced MNPCEs. However, a significant reduction of MNPCEs was also observed when TCL was administered in combination with the chemotherapeutic agent DXR. The analysis of the PCE/NCE ratio revealed no significant differences between the $\mathrm{NaCl}$ control, all doses of TCL, and DXR. However, there were significant differences in the $\mathrm{PCE} / \mathrm{NCE}$ ratio between positive NEU control and all other treatments. The PCE/NCE ratio observed after treatment with TCL and DXR showed significant differences and intermediate values to controls ( $\mathrm{NaCl}$ and NEU). This study suggests absence of genotoxicity and cytotoxicity of TCL, regardless of dose, sex, and time. TCL reduced genotoxic effects induced by DXR, suggesting potential antigenotoxic effects.
\end{abstract}

Keywords: bone marrow, cacao, cytotoxicity, doxorubicin hydrochloride (DXR), phytotherapeutic, rodents.

\section{Diminuição da genotoxicidade induzida por DXR e efeitos não genotóxicos de Theobroma cacao revelados pelo ensaio de micronúcleo}

\section{Resumo}

Este estudo avaliou a genotoxicidade do extrato glicólico liofilizado de sementes de Theobroma cacao Linné (TCL), usando o ensaio do micronúcleo em medula óssea de camundongos. A interação entre TCL e doxorrubicina (DXR) foi também analisada. Grupos experimentais foram avaliados 24-48 h após tratamento com N-Nitroso-N-etilureia (NEU: $50 \mathrm{mg} / \mathrm{kg}), \mathrm{DXR}(5 \mathrm{mg} / \mathrm{kg}), \mathrm{NaCl}(145 \mathrm{mM})$, TCL $(0,5-2 \mathrm{~g} / \mathrm{kg})$, e TCL $(2 \mathrm{~g} / \mathrm{kg})$ em combinação com DXR (ensaio antigenotóxico). As análises de eritrócitos policromáticos micronucleados (EPCMNs) não mostraram diferenças significantes entre todas as doses de tratamento do TCL e o controle $\mathrm{NaCl}$. Camundongos experimentalmente tratados com DXR e NEU induziram significativamente EPCMNs. Contudo, uma redução significante de EPCMNs foi também observada quando TCL foi administrada em combinação com o agente quimioterapêutico DXR. As análises da relação EPC/ENC (eritrócito policromático/eritrócito normocromático) revelaram ausência de diferenças significantes entre o controle $\mathrm{NaCl}$, todas as doses de TCL e DXR. Contudo, houve diferenças significantes na relação EPC/ENC entre o controle positivo NEU e todos os outros tratamento. A relação ECP/ENC observada após o tratamento com TCL e DXR mostrou diferenças significantes e valores intermediários aos controles ( $\mathrm{NaCl}$ e NEU). Este estudo sugere ausência de genotoxicidade e citotoxicidade de TCL, independentemente da dose, sexo e tempo. TCL reduziu os efeitos genotóxicos induzidos por DXR, sugerindo potencial efeitos antigenotóxicos.

Palavras-chave: medula óssea, cacao, citotoxicidade, cloridrato de doxorrubicina (DXR), fitoterapêutico, roedores. 


\section{Introduction}

Theobroma cacao L. (Sterculiaceae family) is a species of neotropical origin that grows between a latitude of $18^{\circ} \mathrm{C}$ North and $15^{\circ} \mathrm{C}$ South (Murillo et al., 2011). This arboreal species is a perennial and xenogamic woody plant, presenting high economic impact (ICCO, 2013; Reis et al., 2015) because of its use as raw material in the production of chocolate, cosmetics, fine beverages, jams, ice creams, among others (Souza et al., 2014). Historically, the consumption of cocoa (T. cacao L.) and its seeds - dried and fermented by Mayan and Aztec civilizations - has been documented since 1,100 BC (Hurst et al., 2002). In Brazil, according to old reports (over 100 years ago), the southeast region of Bahia State has stood out worldwide by its high cocoa production (Souza et al., 2014).

The biochemical composition of cocoa powder presents a high content of fibers (26-40\%), proteins (15-20\%), carbohydrates (15\%), lipids (10-24\%), as well as minerals and vitamins (Ramiro-Puig and Castell, 2009). Other phytochemical tests also revealed high levels of flavonoid and nonflavonoid phenols and methylxanthines (Kim et al., 2014; Ptolemy et al., 2010; Ramiro-Puig and Castell, 2009), and high content of theobromine (Sugimoto et al., 2014). About 380 chemical compounds were registered from T. cacao L. (Andújar et al., 2012) and several studies reported its chemical composition and its bioactive compounds are potentially beneficial to human health (Baharum et al., 2014; Ramiro et al., 2007) and to swine livestock production (Jang et al., 2016; Magistrelli et al., 2016), but toxic to dogs depending on the dose (Gwaltney-Brant et al., 2001) and on the CYP1A2 $1117 \mathrm{C}>\mathrm{T}$ genetic polymorphism (Bates et al., 2015).

Its phytochemical bioavailability is variable (Williamson and Manach, 2005) and dependent on factors such as effectiveness, accumulation and target tissue, molecular size, in vivo modulating factors, as well as metabolic conversion and urinary elimination (Kim et al., 2014; Schewe et al., 2008). From the perspective of preclinical and clinical studies, potentially beneficial effects of $T$. cacao L. have been reported in the literature, including the following activities: antioxidant (reducing agents, free radical scavengers, metal chelators) (Engler and Engler, 2006), anti-inflammatory (Gu et al., 2014), antiatherogenic (Vinson et al., 2006), anticancer (Ohno et al., 2009; Weisburger, 2001), antitumor (Osakabe et al., 2000), and antimutagenic and anticlastogenic in vitro (Yamagishi et al., 2000; Yamagishi et al., 2001). T. cacao L. also helps the treatment of obesity, diabetes, skin aging, anemia, mental fatigue, tuberculosis, fever, gout, kidney stone, and libido improvement (Corti et al., 2009; Dillinger et al., 2000).

Although several studies have supported the efficacy of the therapeutic potential of different forms of preparation and production of T. cacao L. or of its isolated phytochemical compounds, only a few studies aimed at understanding its mutagenic and genotoxic in vivo effects have been carried out: effect of cocoa and theobromine on sister chromatid exchange (SCE) assay and micronucleus assay in Chinese hamsters (Renner and Münzner, 1982); effects of cocoa polyphenols on micronucleus assay in bone marrow cells and peripheral blood of mice (Yamagishi et al., 2001); and effect of cocoa liquor proanthocyanidins on breast and pancreatic carcinogenesis induced by 2-amino-1-methyl-6-phenylimidazo[4,5-b]pyridine (PhIP) in Sprague Dawley rats (Yamagishi et al., 2002).

The genotoxic effects of a potential mutagen depend on its cellular target(s). Some chemicals need to be metabolized before acquiring their mutagenic capacity (Mateuca et al., 2006). Mutagens can induce genomic changes by directly or indirectly targeting DNA or by binding to proteins involved in the maintenance of genome integrity (Kirsch-Volders et al., 2003). The consequences of mutagen-target interactions may lead to different types of DNA damage (DNA adducts, alkali-labile sites, strand breaks) and mutations ranging from single nucleotide changes (gene mutations) to structural (chromosome mutations) or numerical chromosome changes (genome mutations). The fate of the cell is ultimately determined by whether the various lesions inflicted on the genome are repaired or eliminated by apoptosis (Decordier et al., 2002).

As far as genotoxicity studies are concerned, the in vivo micronucleus ( $\mathrm{MN}$ ) assay in rodent bone marrow plays a crucial role in the test battery aimed at identifying hazardous mutagens (Mateuca et al., 2006); this assay is especially suited to assessing mutagenic hazards because it allows consideration of multiple factors, such as in vivo metabolism, pharmacokinetics, and DNA repair processes, even though these processes vary among species, tissues, and genetic endpoints (OECD, 2016). In addition, understanding the genotoxic effects induced by phytotherapeutics and foods employing the mammalian in vivo $\mathrm{MN}$ assay has been the goal of several research groups (Venkatesh et al., 2007; Alves et al., 2013; Boriollo et al., 2014b, 2018).

This study evaluated the genotoxic effects (clastogenicity and/or aneugenicity) of the lyophilized glycolic extract of T. cacao L. (TCL) using the in vivo micronucleus assay in bone marrow of Swiss albinus heterogenetic mice (Unib: SW). The action of TCL on the DXR-induced genotoxic effects (chemotherapeutic agent) was also analyzed (i.e., antigenotoxic evaluation).

\section{Material and Methods}

\subsection{Phytotherapeutic}

Theobroma cacao L. was commercially purchased and stored according to the manufacturer's recommendations [glycolic extract of Theobroma cacao L. seeds (TCL), cod. \# AKSY L02166102308-8, AKSY Comercial Ltda., São Bernardo do Campo, SP, Brazil]. Aliquots (1.5 L) of this extract were submitted to solvent removal proceedings by rotary evaporation (40 rpm) (Rotary Evaporator RV 10 Control V, IKA ${ }^{\circledR}$ Works, Inc., USA) coupled in bath heating systems $\left(40^{\circ} \mathrm{C}\right)$ (Heating Baths HB10, IKA ${ }^{\circledR}$ Works, Inc., USA), vacuum pump (175 mbar) (Chemistry diaphragm pump MD 1C, VACUUBRAND GMBH + CO KG, Wertheim, Germany), distilled water recirculator $\left(10^{\circ} \mathrm{C}\right)$ 
(Banho Ultratermostatizado Microprocessado Digital, SPLABOR, cod. \# SP-152/10, Presidente Prudente, SP, Brazil), and evaporation bottle (RV 10.85 Evaporation Flask, NS 29/32-2L, IKA ${ }^{\circledR}$ Works, Inc., USA). The final product was transferred to 1 L reaction bottle $\left(\mathrm{SCHOTT}^{\circledR}{ }^{\circledR} \mathrm{DURAN}^{\circledR}\right)$ and kept at $-20^{\circ} \mathrm{C}$ for 24 hours, to evaluate the freezing of the final product and the efficacy of the solvent evaporation process (Boriollo et al., 2014b, 2018).

Then, aliquots $(40 \mathrm{ml})$ of this final product were transferred to penicillin glass vials $(50 \mathrm{ml})$ and lyophilized $\left(0.12\right.$ mbar at $-50^{\circ} \mathrm{C}$ ) (Lyophilizer model Alpha 1-2 LDPlus, Martin Christ Gefriertrocknungsanlagen $\mathrm{GmbH}^{\odot}$, Germany), and their dry mass was measured (Electronic Analytical Balance AUW-220D, Shimadzu Corp., Kyoto, Japan). The lyophilized final product was prepared in aqueous solvent (water type 1, Sistema Milli-Q Direct 8, Millipore Indústria e Comércio Ltda., Barueri, SP, Brazil) at concentrations of $2 \times$, sterilized by filtration (Millipore Corporation, hydrophilic Durapore ${ }^{\circledR}$ PVDF, $0.22 \mu \mathrm{m}$, $\varnothing 47 \mathrm{~mm}$, cat. \# GVWP 047 00), and stored in sterile polypropylene tubes $\left(50 \mathrm{ml}\right.$ at $-70^{\circ} \mathrm{C}$ until moment of use).

\subsection{System - in vivo test}

Healthy, heterogeneous, young adult male and female Swiss albinus (Unib: SW) mice (between 7 and 12 weeks - pubescent period), with a body weight between $30 \mathrm{~g}$ and $40 \mathrm{~g}$ (i.e., the variation weight between the animals, for each sex, should not exceed the $\pm 20 \%$ of mean mass) were provided by CEMIB (Multidisciplinary Center for Biological Research - UNICAMP), and erythrocytes from the bone marrow of these mice were used in the micronucleus assay (Boriollo et al., 2014b, 2018; OECD, 2016; Venkatesh et al., 2007). The animals were kept in groups of the same sex, in polypropylene boxes, in an air-conditioned environment to $22^{\circ} \mathrm{C} \pm 3^{\circ} \mathrm{C}$, with relative air humidity of $50-60 \% \pm 10 \%$, and with 12 -hour day-night cycles (i.e., $12 \mathrm{~h}$ light and $12 \mathrm{~h}$ dark). They were fed with Purina ${ }^{\circledR}$ Labina commercial pet food (Nestlé Purina Pet Care Company) and water ad libitum, and acclimated to laboratory conditions for 7 days (a trial period) before the execution of the experiment. At the end of the trial period, each animal was weighed and, according to the weight, received $1 \mathrm{ml} / 100 \mathrm{~g}$ body weight of the indicated liquid (negative control, positive control, chemotherapeutic, and phytotherapeutic). After the experimental treatment, the animals were euthanized by $\mathrm{CO}_{2}$ asphyxiation in adapted acrylic chambers. This research was approved by Ethics Committee in Research Involving Animals (Protocol No. 08A/2014).

\subsection{Experimental groups}

Groups of animals (consisting of 5 males and 5 females each) were treated using a single dosing regimen administered by gavage (phytotherapeutic and negative control) or intraperitoneally (chemotherapeutic and positive control) and two euthanasia times (24 and $48 \mathrm{~h}$ ), based on a regulatory recommendation regarding the in vivo micronucleus assay (Boriollo et al., 2014b, 2018; OECD, 2016; Venkatesh et al., 2007):

- Control groups: $150 \mathrm{mM} \mathrm{NaCl}$ (negative control), $50 \mathrm{mg} / \mathrm{kg}$ of N-Nitroso-N-ethylurea (positive control: NEU, Sigma N8509, CAS no. 759-73-9), and $5 \mathrm{mg} / \mathrm{kg}$ of doxorubicin hydrochloride (chemotherapeutic: DXR, Eurofarma Laboratórios Ltda., CAS no. 23214-92-8);

- Genotoxicity test (phytotherapeutic): 0.5, 1.0, 1.5, and $2.0 \mathrm{~g} / \mathrm{kg}$ of TCL lyophilized and diluted in water type 1 . The maximum tolerated dose (MTD) was defined as $(i)$ the highest dose that can be administered without inducing lethality or excessive toxicity during the study, causing moribund euthanasia, or ( $i i)$ a dose that produces some indication of toxicity of the bone marrow (e.g. a reduction in the proportion of immature erythrocytes among total erythrocytes in the bone marrow), or (iii) $2.0 \mathrm{~g} / \mathrm{kg}$;

- Antigenotoxicity test 1 (phytotherapeutic + chemotherapeutic): TCL ( $2.0 \mathrm{~g} / \mathrm{kg})+\mathrm{DXR}(5 \mathrm{mg} / \mathrm{kg})$.

\subsection{Processing the bone marrow and cell analysis}

Shortly after euthanasia, the femora were surgically and aseptically removed, and the animals were appropriately discarded. Each femur was sectioned at the proximal end and the contents of the spinal canal were washed with $1.5 \mathrm{ml}$ of $150 \mathrm{mM} \mathrm{NaCl}$ solution and transferred to a $15 \mathrm{ml}$ centrifuge tube. This material was resuspended with a Pasteur pipette to ensure a random distribution of bone marrow cells. The suspension was then centrifuged at 1,000 rpm (Centrifuga de Bancada Microprocessada, Mod. NT 810, Nova Técnica Ind. e Com. de Equip. para Laboratório Ltda., Piracicaba, SP, Brazil) for 5 minutes. The supernatant was discarded and the resulting sediment was resuspended in $500 \mu \mathrm{l}$ of $150 \mathrm{mM} \mathrm{NaCl}$ solution added with $4 \%$ formaldehyde. The slides were prepared by smearing ( 2 slides per animal), dried at room temperature for $24 \mathrm{~h}$, and stained with Leishman's eosin methylene blue dye [pure dye for $3 \mathrm{~min}$, followed by diluted dye in water type $1(1: 6)$ for $15 \mathrm{~min}$ ] to differentiate polychromatic erythrocyte (PCE) from normochromatic erythrocyte (NCE) (Boriollo et al., 2014b, 2018; OECD, 2016; Venkatesh et al., 2007).

Polychromatic erythrocytes (PCEs) were observed at a magnification of $1,000 \times$ using optical microscopy (Nikon Eclipse E-200), counted (at least 4,000 anucleated polychromatic erythrocytes per animal were scored for the incidence of micronucleated polychromatic erythrocytes) with the aid of a digital cell counter (Contador Diferencial CCS02, Kacil Indústria e Comércio Ltda., PE, Brasil Contador Diferencial CCS02, Kacil Indústria e Comércio Ltda., PE, Brazil), and photographed using an 8.1 Megapixel Digital Camera (DC FWL 150). The number of PCEs and NCEs and the number and frequency of micronucleated polychromatic erythrocytes (MNPCEs) were reported. To evaluate bone marrow toxicity, the ratio of PCE to NCE 
was also observed. This PCE/NCE ratio is an indicator of the acceleration or inhibition of erythropoiesis and it has been reported to vary with scoring time. A continuous decline in the PCE/NCE ratio may occur because of inhibition of cell division, killing of erythroblasts, removal of damaged cells, or dilution of the existing cell pool with newly formed cells (Boriollo et al., 2014b, 2018; OECD, 2016; Venkatesh et al., 2007).

\subsection{Statistical analysis}

The data obtained in the micronucleus assay were submitted to one-way analysis of variance (ANOVA), using a factorial scheme of $8 \times 2 \times 2$ (treatment $\times$ sex $\times$ euthanasia time), and to mean comparison with Tukey's test $(p<0.05)$ using $\mathrm{SAS}^{\circledR}$ version 9.2.

\section{Results and Discussion}

The MNPCEs ( $n$ and \%) and the PCE/ NCE ratio in the bone marrow of heterogeneous Swiss albinus (Unib: SW) mice were analyzed statistically for each one of the animal groups treated with only TCL - genotoxic assay $(0.5,1.0,1.5$, and $2 \mathrm{~g} / \mathrm{kg}$ of TCL) - and for the groups treated with phytotherapeutic and chemotherapeutic agent - antigenotoxic assay ( $2 \mathrm{~g} / \mathrm{kg}$ of TCL $+5 \mathrm{mg} / \mathrm{kg}$ of DXR) -, as well as for control groups $(\mathrm{NaCl} 150 \mathrm{mM}$, NEU $50 \mathrm{mg} / \mathrm{kg}$, or DXR $5 \mathrm{mg} / \mathrm{kg}$ ).

For animal groups treated with TCL, the MNPCE analysis showed no significant differences $(p<0.05)$ between all the treatment doses $(0.5-2 \mathrm{~g} / \mathrm{kg})$ [average values (\%) of $0.26 \pm 0.10(24 \mathrm{~h})$ and $0.32 \pm 0.34(48 \mathrm{~h})$ for $500 \mathrm{mg} / \mathrm{kg} ; 0.26 \pm 0.12(24 \mathrm{~h})$ and $0.25 \pm 0.14(48 \mathrm{~h})$ for $1,000 \mathrm{mg} / \mathrm{kg} ; 0.38 \pm 0.14(24 \mathrm{~h})$ and $0.29 \pm 0.21$ (48 h) for $1,500 \mathrm{mg} / \mathrm{kg}$; and $0.75 \pm 0.31(24 \mathrm{~h})$ and $0.42 \pm 0.29(48 \mathrm{~h})$ for $2,000 \mathrm{mg} / \mathrm{kg}$ ] and negative control $(\mathrm{NaCl})$ [average values (\%) of $0.44 \pm 0.10(24 \mathrm{~h})$ and $0.50 \pm 0.08(48 \mathrm{~h})$ ] (Table 1). These results suggested that TCL was not genotoxic, regardless of the dose administered (Figure 1C), the sex of the animal (male or female) (Figure 1B), or the treatment time (24 or $48 \mathrm{~h}$ ) (Figure 1A). Mice experimentally treated with DXR (5 mg/kg) significantly induced MNPCE 24 and

Table 1. The incidence of MNPCEs and PCE/NCE ratio in bone marrow of male and female Swiss albinus mice after testing for $24 \mathrm{~h}$ and $48 \mathrm{~h}$. Shown are data from the controls (NaCl, NEU and DXR), an evaluation of the genotoxicity of the $T$. cacao L. seeds (TCL), and an evaluation of the antigenotoxicity of TCL seeds (TCL + DXR).

\begin{tabular}{|c|c|c|c|c|c|c|}
\hline \multirow{2}{*}{ Treatment } & \multicolumn{2}{|c|}{ MNPCEs $(n)$} & \multicolumn{2}{|c|}{ MNPCEs (\%) } & \multicolumn{2}{|c|}{ PCE / (PCE + NCE) } \\
\hline & $24 h^{A}$ & $48 h^{A}$ & $24 h^{A}$ & $48 h^{A}$ & $24 h^{A}$ & $48 h^{A}$ \\
\hline O $\mathbf{A}$ (MNPCE); $\mathbf{A}$ (PCE/NCE ratio) & $9 \pm 2$ & $9 \pm 1$ & $0.43 \pm 0.10$ & $0.45 \pm 0.06$ & $1.00 \pm 0.01$ & $1.00 \pm 0.01$ \\
\hline$\widehat{\delta} \mathbf{A}(\mathrm{MNPCE}) ; \mathbf{A}(\mathrm{PCE} / \mathrm{NCE}$ ratio) & $9 \pm 3$ & $12 \pm 1$ & $0.45 \pm 0.12$ & $0.56 \pm 0.05$ & $0.99 \pm 0.01$ & $0.99 \pm 0.00$ \\
\hline Mean \pm SD $(150 \mathrm{mM} \mathrm{NaCl})$ & $9 \pm 2^{A}$ & $11 \pm 2^{\mathrm{A}}$ & $0.44 \pm 0.10^{\mathrm{A}}$ & $0.50 \pm 0.08^{\mathrm{A}}$ & $0.99 \pm 0.01^{\mathbf{A}}$ & $0.99 \pm 0.01^{\mathrm{A}}$ \\
\hline O $\mathbf{A}$ (MNPCE); $\mathbf{A}$ (PCE/NCE ratio) & $28 \pm 12$ & $34 \pm 3$ & $1.41 \pm 0.57$ & $1.66 \pm 0.07$ & $0.55 \pm 0.06$ & $0.80 \pm 0.14$ \\
\hline$\widehat{\delta} \mathbf{A}(\mathrm{MNPCE}) ; \mathbf{A}(\mathrm{PCE} / \mathrm{NCE}$ ratio) & $65 \pm 40$ & $36 \pm 5$ & $3.20 \pm 1.96$ & $1.83 \pm 0.27$ & $0.53 \pm 0.13$ & $0.52 \pm 0.15$ \\
\hline Mean \pm SD (NEU 50 mg/kg) & $47 \pm 33^{\text {в }}$ & $35 \pm 4^{\text {B }}$ & $2.30 \pm 1.62^{\text {в }}$ & $1.75 \pm 0.20^{\text {в }}$ & $0.54 \pm 0.09^{\mathrm{C}}$ & $0.66 \pm 0.20^{\mathrm{C}}$ \\
\hline O $\mathbf{A}$ (MNPCE); $\mathbf{A}$ (PCE/NCE ratio) & $60 \pm 12$ & $50 \pm 14$ & $2.86 \pm 0.57$ & $2.40 \pm 0.63$ & $0.85 \pm 0.13$ & $0.97 \pm 0.02$ \\
\hline$\widehat{A}$ (MNPCE); $\mathbf{A}$ (PCE/NCE ratio) & $52 \pm 5$ & $60 \pm 10$ & $2.49 \pm 0.26$ & $2.92 \pm 0.51$ & $0.98 \pm 0.01$ & $0.97 \pm 0.02$ \\
\hline Mean \pm SD (DXR 5 mg/kg) & $56 \pm 9^{\mathrm{C}}$ & $55 \pm 12^{\mathrm{C}}$ & $2.68 \pm 0.44^{\mathrm{C}}$ & $2.66 \pm 0.58^{\mathrm{C}}$ & $0.92 \pm 0.11^{\mathbf{A}}$ & $0.97 \pm 0.02^{\mathrm{A}}$ \\
\hline O $\mathbf{A}$ (MNPCE); $\mathbf{A}$ (PCE/NCE ratio) & $5 \pm 1$ & & $0.24 \pm 0.05$ & $0.43 \pm 0.50$ & $0.99 \pm 0.01$ & $0.99 \pm 0.01$ \\
\hline$\widehat{A} \mathbf{A}(\mathrm{MNPCE}) ; \mathbf{A}(\mathrm{PCE} / \mathrm{NCE}$ ratio) & $6 \pm 3$ & $4 \pm 1$ & $0.29 \pm 0.15$ & $0.21 \pm 0.06$ & $1.00 \pm 0.01$ & $0.99 \pm 0.01$ \\
\hline Mean \pm SD (TCL 500 mg/kg) & $6 \pm 2^{A}$ & $7 \pm 7^{\mathrm{A}}$ & $0.26 \pm 0.10^{\mathrm{A}}$ & $0.32 \pm 0.34^{\mathrm{A}}$ & $1.00 \pm 0.01^{\mathrm{A}}$ & $0.99 \pm 0.01^{\mathrm{A}}$ \\
\hline O A (MNPCE); $\mathbf{A}$ (PCE/NCE ratio) & $3 \pm 2$ & $7 \pm 3$ & $0.16 \pm 0.07$ & $0.33 \pm 0.15$ & $1.00 \pm 0.00$ & $1.00 \pm 0.00$ \\
\hline$\widehat{A}$ (MNPCE); $\mathbf{A}$ (PCE/NCE ratio) & $8 \pm 1$ & $3 \pm 2$ & $0.36 \pm 0.03$ & $0.16 \pm 0.07$ & $1.00 \pm 0.00$ & $0.99 \pm 0.01$ \\
\hline Mean \pm SD $($ TCL $1,000 \mathrm{n}$ & $6 \pm 3^{A}$ & $5 \pm 3^{A}$ & $0.26 \pm 0.12^{\mathrm{A}}$ & $0.25 \pm 0.14^{\mathrm{A}}$ & $1.00 \pm 0.00^{\mathrm{A}}$ & $1.00 \pm 0.01^{\mathrm{A}}$ \\
\hline of $\mathbf{A}$ (MNPCE); $\mathbf{A}$ (PCE/NCE ratio) & $8 \pm 2$ & $9 \pm 3$ & $0.40 \pm 0.10$ & $0.45 \pm 0.14$ & $1.00 \pm 0.00$ & $1.00 \pm 0.01$ \\
\hline$\widehat{A}$ (MNPCE); $\mathbf{A}$ (PCE/NCE ratio) & $7 \pm 4$ & $3 \pm 3$ & $0.35 \pm 0.19$ & $0.13 \pm 0.12$ & $0.99 \pm 0.02$ & $0.98 \pm 0.01$ \\
\hline Mean \pm SD (TCL 1,500 n & $8 \pm 3^{A}$ & $6 \pm 4^{\mathrm{A}}$ & $0.38 \pm 0.14^{\mathrm{A}}$ & $0.29 \pm 0.21^{\mathrm{A}}$ & $1.00 \pm 0.01^{\mathrm{A}}$ & $0.99 \pm 0.01^{\mathrm{A}}$ \\
\hline o $\mathbf{A}$ (MNPCE); $\mathbf{A}$ (PCE/NCE ratio) & $16 \pm 7$ & $11 \pm 9$ & $0.78 \pm 0.33$ & $0.54 \pm 0.40$ & $1.00 \pm 0.01$ & $1.00 \pm 0.00$ \\
\hline$\widehat{A} \mathbf{A}(\mathrm{MNPCE}) ; \mathbf{A}$ (PCE/NCE ratio) & $15 \pm 8$ & $6 \pm 2$ & $0.72 \pm 0.36$ & $0.29 \pm 0.08$ & $0.97 \pm 0.03$ & $0.96 \pm 0.05$ \\
\hline Mean \pm SD (TCL 2,000 mg/kg) & $16 \pm 7^{\mathrm{A}}$ & $9 \pm 6^{A}$ & $0.75 \pm 0.31^{\mathbf{A}}$ & $0.42 \pm 0.29^{\mathrm{A}}$ & $0.99 \pm 0.02^{\mathrm{A}}$ & $0.98 \pm 0.04^{\mathrm{A}}$ \\
\hline o $\mathbf{A}$ (MNPCE); $\mathbf{A}$ (PCE/NCE ratio) & $20 \pm 8$ & $9 \pm 5$ & $0.99 \pm 0.37$ & $0.42 \pm 0.24$ & $0.80 \pm 0.11$ & $0.79 \pm 0.08$ \\
\hline$\widehat{\delta} \mathbf{A}(\mathrm{MNPCE}) ; \mathbf{A}(\mathrm{PCE} / \mathrm{NCE}$ ratio $)$ & $14 \pm 6$ & $8 \pm 7$ & $0.68 \pm 0.29$ & $0.41 \pm 0.33$ & $0.85 \pm 0.18$ & $0.60 \pm 0.14$ \\
\hline Mean \pm SD (TCL 2 g/kg + DXR) & $17 \pm 7^{\mathrm{A}}$ & $9 \pm 5^{\mathrm{A}}$ & $0.84 \pm 0.34^{\mathrm{A}}$ & $0.42 \pm 0.26^{\mathrm{A}}$ & $0.83 \pm 0.14^{\text {в }}$ & $0.70 \pm 0.15^{\text {в }}$ \\
\hline $\begin{array}{l}\text { Ieans with the same letter (A. B } \\
\text { d DXR), an evaluation of the } g \\
\text { CL + DXR). } q \text { and } \delta \text { correspo }\end{array}$ & 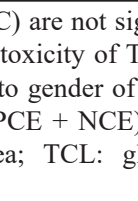 & $.5-2 \mathrm{~g}$ & in & 10 & . & $\begin{array}{l}(\mathrm{NaCl}, \mathrm{NEU} \\
\mathrm{L}(2.0 \mathrm{~g} / \mathrm{kg})\end{array}$ \\
\hline
\end{tabular}



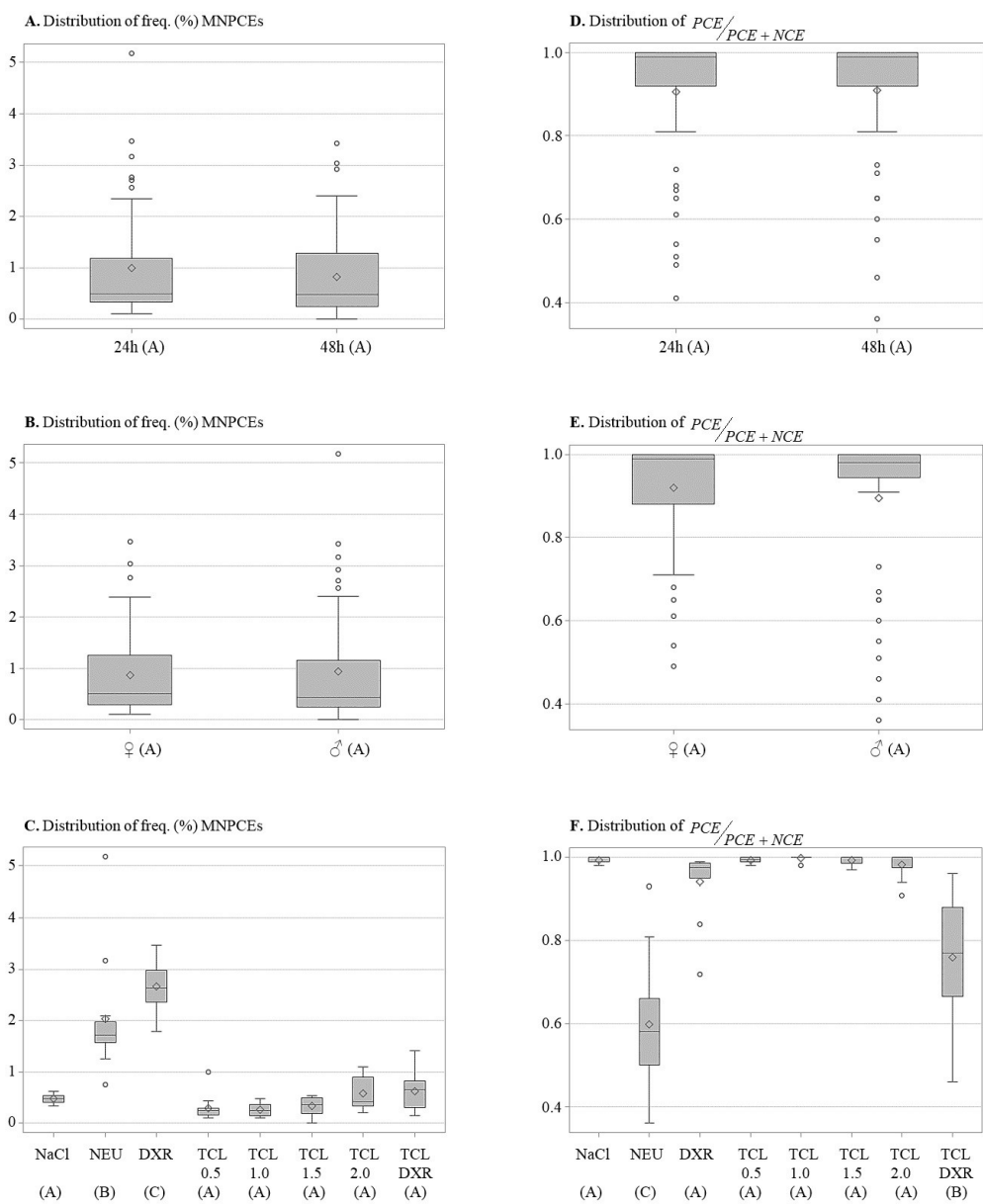

Figure 1. Box-plots showing the incidence of micronucleated polychromatic erythrocytes (MNPCEs) and ratio of polychromatic erythrocytes (PCE) to normochromatic erythrocytes (NCE) in bone marrow of male (ठ) ) and female ( + ) Swiss albinus mice after testing for $24 \mathrm{~h}$ and $48 \mathrm{~h}$. Shown are data from the controls $(150 \mathrm{mM} \mathrm{NaCl}, \mathrm{NEU} 50 \mathrm{mg} / \mathrm{kg}$ and DXR $5 \mathrm{mg} / \mathrm{kg}$ ), an evaluation of the genotoxicity of the $T$. cacao L. seeds (TCL: $0.5-2 \mathrm{~g} / \mathrm{kg}$ ), and an evaluation of the antigenotoxicity of TCL (THI $2.0 \mathrm{~g} / \mathrm{kg}+$ DXR $5 \mathrm{mg} / \mathrm{kg}$ ). Means with the same letter (A, B or C) are not significantly different $(p<0.05)$.

$48 \mathrm{~h}$ after treatment and for both sexes [average values $(\%)$ of $2.68 \pm 0.44(24 \mathrm{~h})$ and $2.66 \pm 0.58(48 \mathrm{~h})]$, with MNPCE frequencies significantly above those observed in the positive NEU control ( $50 \mathrm{mg} / \mathrm{kg}$ ) [average values (\%) of $2.30 \pm 1.62(24 \mathrm{~h})$ and $1.75 \pm 0.20(48 \mathrm{~h})$ ] (Figure 1C). The significant reduction $(p<0.05)$ of MNPCE ( $n$ and \%) was also observed when TCL $(2 \mathrm{~g} / \mathrm{kg})$ was administered in combination with the chemotherapeutic agent DXR $(5 \mathrm{mg} / \mathrm{kg})$ [average values (\%) of $0.84 \pm 0.34(24 \mathrm{~h})$ and $0.42 \pm 0.26(48 \mathrm{~h})]$ (Table 1 and Figure 1C), suggesting antigenotoxic effects (anticlastogeny and/or antianeugeny) of TCL. Thus, TCL potentially confers protection against DXR-induced genotoxic effects in the bone marrow of mice, regardless of the treatment time ( 24 or $48 \mathrm{~h}$ ) or the sex of the animal.

The analysis of the PCE/NCE ratio revealed no significant differences $(p<0.05)$ between the negative control $(\mathrm{NaCl})$ [average values of $0.99 \pm 0.01(24 \mathrm{~h})$ and $0.99 \pm 0.01(48 \mathrm{~h})$ ], all doses of TCL [average values of $1.00 \pm 0.01(24 \mathrm{~h})$ and $0.99 \pm 0.01(48 \mathrm{~h})$ for $500 \mathrm{mg} / \mathrm{kg}$;
$1.00 \pm 0.00(24 \mathrm{~h})$ and $1.00 \pm 0.01(48 \mathrm{~h})$ for $1,000 \mathrm{mg} / \mathrm{kg}$; $1.00 \pm 0.01(24 \mathrm{~h})$ and $0.99 \pm 0.01(48 \mathrm{~h})$ for $1,500 \mathrm{mg} / \mathrm{kg}$; and $0.99 \pm 0.02(24 \mathrm{~h})$ and $0.98 \pm 0.04(48 \mathrm{~h})$ for $2,000 \mathrm{mg} / \mathrm{kg}]$, and the chemotherapeutic agent DXR $(5 \mathrm{mg} / \mathrm{kg})$ [average values of $0.92 \pm 0.11(24 \mathrm{~h})$ and $0.97 \pm 0.02(48 \mathrm{~h})]$. However, there were significant differences in the PCE/NCE ratio between positive NEU control $(50 \mathrm{mg} / \mathrm{kg})$ [average values of $0.54 \pm 0.09(24 \mathrm{~h})$ and $0.66 \pm 0.20(48 \mathrm{~h})]$ and all other treatments (Table 1 and Figure 1F). These results suggested that TCL had no systemic toxicity under MN assay conditions, regardless of time (24 and $48 \mathrm{~h}$ ) (Figure 1D), sex (male and female) (Figure 1E), and phytotherapeutic dose $(0.5-2.0 \mathrm{~g} / \mathrm{kg})$ (Figure $1 \mathrm{~F})$.

Interestingly, the PCE/NCE ratio observed after treatment with TCL $(2 \mathrm{~g} / \mathrm{kg})$ and DXR $(5 \mathrm{mg} / \mathrm{kg})$ [average values of $0.83 \pm 0.14(24 \mathrm{~h})$ and $0.70 \pm 0.15(48 \mathrm{~h})]$ in antigenotoxic assays showed significant differences $(p<0.05)$ and intermediate values to negative control [average value of $0.99 \pm 0.01(24 \mathrm{~h})$ and $0.99 \pm 0.01(48 \mathrm{~h})]$ and positive control [average values of $0.54 \pm 0.09$ (24 h) and 
$0.66 \pm 0.20(48 \mathrm{~h})]$ (Figure 1F). These results suggested that TCL combined with the chemotherapeutic agent (DXR) favored moderate systemic toxicity (i.e., observed by the decrease of the PCE/NCE ratio) regardless of the sex of the animal or the treatment time, although TCL has reduced the genotoxicity of DXR (i.e., observed by the decrease of the MNPCE frequency). The evaluation of the potentially antigenotoxic effects (chemotherapeutic + phytotherapeutic) associated with the absence of systemic toxicity of TCL could be determined from dosages $<2,000 \mathrm{mg} / \mathrm{kg}$, or from the identification, purification, and exploitation of the phytochemical compounds in TCL.

Doxorubicin (DXR) is a chemically synthesizable antibiotic and it was initially isolated from Streptomyces peacetius. DXR belongs to a class of chemotherapeutic drugs named anthracyclines with a large spectrum of activity (Varela-López et al., 2019). The mechanisms of action of DXR (common both to the cancer cells and healthy cells) have been described as DNA alterations associated to the presence of DXR in the nucleus (e.g., actions on topoisomerase II, formation of doxorubicin-DNA adducts, and alterations in the topology of DNA and nucleosome destabilization), ceramide overproduction, production of free radicals and ROS (e.g., formation of semiquinone radicals by $\mathrm{NAD}(\mathrm{P}) \mathrm{H}$-oxidoreductases, activation of $\mathrm{NAD}(\mathrm{P})$ $\mathrm{H}$-oxidoreductases, alterations of nitric oxide synthases, mitochondrial dysfunction, iron-coupling and production of hydroxyl radicals, and disturbances in calcium homeostasis), and DOX interactions with autophagy (Varela-López et al., 2019). In additon, DXR has been reported to induce chromatid and chromosome aberrations, DNA single- and double-strand breaks, and micronuclei in vivo and in vitro (Al-Shabanah, 1993; Bean et al., 1992; Boriollo et al., 2014b, 2018; Delvaeye et al., 1993; Dhawan et al., 2003; Jagetia and Nayak, 2000; Venkatesh et al., 2007).

Genotoxic effects of anticancer drugs is of special interest because of the risk of inducing secondary malignancies. In this sense, screening for newer agents that can protect the normal cells against DXR-induced cumulative damages have been considerate essentially important. Multiple plant molecules may be advantageous because some may counteract the toxicity of others, and as a result, the net effect may be beneficial for therapeutic pharmacological purposes. In this context, the effects of some plant species on doxorubicin (DXR)-induced genotoxic effects in mice bone marrow was studied, as for example $A$. marmelos (Venkatesh et al., 2007), C. langsdorffii (Alves et al., 2013), H. annuus (Boriollo et al., 2014b), and Z. joazeiro (Boriollo et al., 2014a), and H. impetiginosus (Boriollo et al., 2018). The treatment of mice with those plants significantly reduced the frequency of DXR-induced micronuclei. Those chemoprotective effects may be assigned to the sum total of interactions between different ingredients of those complex mixtures. The possible mechanisms of action of those plants in protecting against DXR-induced genomic damages were scavenging of $\mathrm{O}_{2}{ }^{-}$and ${ }^{\circ} \mathrm{OH}$ and other free radicals, antioxidant activity of one or more of the active compounds, restoration of topoisomerase II activity, and inhibition of the formation of DXR-iron complex. In addition, the counteracted of the clastogenic consequences of DOX in Wistar rat bone marrow can be explained as a consequence of the antioxidant properties of compounds (for example, vitamin C) at low doses and its pro-oxidant effects with higher doses (Varela-López et al., 2019).

Theobroma cocoa is rich in polyphenols and they have become an intense focus of research because of their beneficial health effects. They have been reported to exhibit anti-carcinogenic, anti-atherogenic, anti-ulcer, anti-thrombotic, anti-inflammatory, anti-allergenic, immune modulating, anti-microbial, vasodilatory, and analgesic effects. Polyphenols exert these effects as antioxidants, chelators of divalent cations, inhibitors of the activity of enzymes including DNA topoisomerase II, protein kinase $\mathrm{C}$ and protein tyrosine kinases, inducers of hepatic electrophile-processing, and as modulators of the activity of enzymes such as cytochrome P-450 isozyme, nitric oxide synthase, cyclo-oxygenase and lipoxygenase (de la Luz Cádiz-Gurrea et al., 2019; Wollgast and Anklam, 2000).

The effects of crude extracts of whole cocoa products on the mutagenicity of benzo[a]pyrene (B[a]P) in Salmonella typhimurium strain TA98 and tert-butyl hydroperoxide (t-BuOOH) in S. typhimurium strain TA102 was investigated by Ames test (Ohno et al., 2009). In this research, cocoa powder extracts and milk chocolate modulated the numbers of revertant colonies produced by $\mathrm{B}[\mathrm{a}] \mathrm{P}$ treatment with metabolic activation in a dose-dependent manner [i.e., the numbers of revertant colonies induced by $\mathrm{B}[\mathrm{a}] \mathrm{P}$ in combination with each dilution of the milk chocolate solution $(0.167,1.67$, and $16.7 \mathrm{mg} /$ plate $)$ were $78.4 \%, 85.6 \%$, and $41.8 \%$ of the control, respectively, and the numbers of revertant colonies induced by $\mathrm{B}[\mathrm{a}]$ $P$ combined with each dilution of cocoa powder extract $(1.325,2.65,6.625$, and $13.25 \mathrm{mg} /$ plate $)$ were $91.2 \%$, $78.5 \%, 48.2 \%$, and $27.3 \%$ of the control, respectively]. This crude cocoa powder extract also reduced EROD (ethoxyresorufin O-deethylase) activity in a dose-dependent manner [i.e., the EROD activities in the presence of each dilution of cocoa powder extract $(1.325,2.65,5.30,7.95$, 10.60 , and $13.25 \mathrm{mg} /$ tube) were $79.4 \%, 74.1 \%, 74.6 \%$, $43.0 \%, 28.3 \%$, and $17.4 \%$ of the control, respectively], suggesting that whole cocoa products inhibit cytochrome P450 (CYP) 1A activity and may prevent DNA damage by reducing metabolic activation of procarcinogens to carcinogens (Ohno et al., 2009).

Mutagenic and antimutagenic effects of ultrafiltrated fractions ( $>30,30-10,10-5$, and $<5 \mathrm{kDa}$ ) of raw, pre-roasted, and roasted cocoa were tested by Salmonella microsome assay (with and without metabolic activation) (Summa et al., 2008). Neither mutagenic nor antimutagenic effects on any of the samples at any of the different concentrations (i.e., $10 \%$ were possible, $5 \%, 2.5 \%, 1 \%, 0.5 \%$, and $0.1 \%$ ) were observed using TA98 (it provides information on frame-shift mutations), TA100 (it provides information on base-pair substitutions), and TA102 strains (it detects cross-linking agents) (Summa et al., 2008). 
The effects of cocoa liquor proanthocyanidins (CLPr) on 2-amino-1-methyl-6-phenylimidazo[4,5-b] pyridine (PhIP)-induced mutagenesis on in vitro and in vivo carcinogenesis in female Sprague-Dawley (SD) rats were investigated. In the Ames assay using Salmonella typhimurium TA98, CLPr showed strong antimutagenic effects against PhIP when assayed in the presence of $\mathrm{S} 9$ mixture. For determination of the influence on initiation and subsequent development of lesions, CLPr $(0.025 \%$ or $0.25 \%$ ) were fed during the period of PhIP application $(100 \mathrm{mg} / \mathrm{kg}$ given to rats via gastric tubes eight times over 4 weeks), or thereafter until the termination at 48 weeks. CLPr treatments did not affect body or organ weights. The incidences, multiplicities, and volumes of mammary tumors in the $0.25 \%$ CLPr (post-initiation) group showed a tendency to decrease compared to PhIP alone group values, although without statistical significance. The incidences of preneoplastic eosinophilic foci in the exocrine pancreas were significantly $(p<0.05)$ decreased in a dose-dependent manner when CLPr were given during the initiation period. These results indicate that CLPr inhibit in vitro mutagenicity of $\mathrm{PhIP}$, as well as rat pancreatic carcinogenesis in the initiation stage, but not PhIP-induced mammary carcinogenesis (Yamagishi et al., 2002).

The effects of cocoa liquor polyphenols [cocoa liquor extract (CLE), cocoa liquor crude polyphenols (CLP), cocoa liquor tannin (CLT), epicatechin (EC), catechin (CA), and quercetin] on the mutagenic action of heterocyclic amines (HCAs: 3-Amino-1-methyl-5H-pyrido[4,3-b]indole Trp-P-2 and 2-Amino-3,4-dimethyl-imidazo[4,5-f]quinoline - MeIQ) were evaluated by Ames test in vitro and by a ex vivo host-mediated assay (Yamagishi et al., 2000). In these studies on the antimutagenicity observed in the Salmonella typhimurium strain TA98 in the presence/absence of the S9 mixture (Ames test of $\mathrm{HCA}$ with the $\mathrm{S} 9$ mixture, Ames test using activated HCA, and Ames test with metabolic activation of HCA), the cocoa compounds were ranked in terms of efficacy (i.e., decrease in the number of revertant colonies) as follows: quercetin $>$ CLT $>$ CLP $>>$ EC $=$ CA. Such results suggested that the antimutagenic mechanism of action of quercetin differs from that of cocoa liquor polyphenols, as the latter can involve not only the suppression of HCA activation. In the intrasanguinous host-mediated assay (ex vivo mutagenicity test) using female BALB/c mice, CLE (500 mg/kg of body weight), culture of $S$. typhimurium strain TA98 $\left(5 \times 10^{10} \mathrm{cfu} / \mathrm{ml}\right)$, and Trp-P-2 (1.5 mg/kg body weight), the results showed a decreased number of revertant colonies for the CLE pretreatment group compared with the control group. These findings suggested that $(i)$ cocoa liquor polyphenols inhibit the metabolic activation of Trp-P-2 in the liver, (ii) cocoa liquor polyphenols have a direct effect on activated Trp-P-2, diminishing its mutagenicity, (iii) cocoa liquor polyphenols induce an anticarcinogenic enzyme, and (iv) cocoa liquor polyphenols inhibit the absorption of orally administered Trp-P-2 in the gastrointestinal tract (Yamagishi et al., 2000).

Earlier studies on the mutagenic activity in instant hot beverage powders (grain-based coffee-substitute blends, instant coffees, and cocoa products) were investigated using Ames test. Additionally, the mutagenic compounds were characterized by chromatographic fractionation and a comparison with the heterocyclic amines formed during the cooking of muscle meats. Mutagenic activity was observed in coffee-substitute blends (S. typhimurium strains TA98, YG1024, and YG1029) and instant coffees (strains TA98 and YG1024), using the standard plate incorporation assay with metabolic activation (S9 fraction). However, no mutagenic activity was observed in the cocoa products and in any of the products without metabolic activation (Johansson et al., 1995).

Another early report about the genotoxicity of cocoa powder (standard grade) was performed using a series of in vitro short-term assays, including Ames assay, mouse lymphoma TK assay, cytogenetic assays for chromosome aberrations (CHO cells), and sister chromatid exchange assay (CHO cells and human lymphocytes), and Balb/c-3T3 cell transformation assay (Brusick et al., 1986). No evidence of mutagenicity was observed in Ames assay $(0.5-5,000 \mu \mathrm{g} /$ plate $)$ using the S. typhimurium strains TA1535, TA1537, TA1538, TA98, and TA 100, with and without metabolic activation systems (S9 fraction). Responses considered biologically insignificant were related in mouse lymphoma assay $(625-6,000 \mu \mathrm{g} / \mathrm{ml})$ under activation and nonactivation treatment conditions. No evidence of clastogenicity was observed in chromosome aberrations assay of cocoa powder $(10-1,000 \mu \mathrm{g} / \mathrm{ml})$ in Chinese hamster ovary (CHO) cells under activation (S9 mixture) and nonactivation treatment conditions. In cell transformation assay, cocoa powder $(0.01-250 \mu \mathrm{g} / \mathrm{ml})$ showed inability to transform mouse Balb/c-3T3 cells in vitro. Culture human lymphocytes treated with cocoa powder $(39-1,250 \mu \mathrm{g} / \mathrm{ml})$ revealed equivalent results to the negative controls, but it was toxic to the cell culture in the highest concentration tested $(2,500 \mu \mathrm{g} / \mathrm{ml})$, using the SCE assay. However, cocoa powder showed SCE frequencies slightly increased in CHO cells under nonactivation test conditions (without S9 fraction) (Brusick et al., 1986).

\section{Conclusions}

In conclusion, this scientific research reports information with emphasis on mutagenesis, in particular on the possible genotoxic and antigenotoxic effects of the glycolic extract of T. cacao L. (TCL), using the in vivo micronucleus assay in the bone marrow of mice. The presented results suggest the absence of genotoxicity (i.e., clastogeny and/or aneugeny) of TCL, regardless of dose $(0.5-2 \mathrm{~g} / \mathrm{kg})$, time (24-48 h), and sex (male and female). Absence of systemic toxicity was observed under the conditions of micronucleus assay, according to the PCE/NCE ratio data. However, the combination of TCL ( $2 \mathrm{~g} / \mathrm{kg})$ with DXR $(5 \mathrm{mg} / \mathrm{kg})$ partly increases systemic toxicity, suggesting that the extract of TCL enhances the DXR-induced toxic effects in the bone marrow of mice (i.e., toxic effect independent of time and sex). 
Other studies involving the genotoxicity of extracts and phytochemical compounds characterized from T. cacao L. should be conducted [e.g., plasmid nicking assay, mouse lymphoma assay, in vitro cytogenetic tests and aneuploidy, in vitro micronucleus test, fluorescence in situ hybridization (FISH) and its application to mutagenesis, comet assay for DNA damage detection and individualized cell repair, functional genomics and proteomics in mutagenesis (cDNA arrays, microarrays analyses), among others], to characterize the potentially genotoxic and antigenotoxic effects and their molecular mechanisms involved and, more importantly, to establish limits for human consumption, to delineate the potential risks to human health, and to implement rational strategies and chemopreventive measures.

\section{Acknowledgements}

This research was supported by Rede Mineira de Ensaios Toxicológicos e Farmacológicos de Produtos Terapêuticos (REDE MINEIRA TOXIFAR), Fundação de Amparo à Pesquisa do Estado de Minas Gerais (FAPEMIG processo no. RED-00008-14) and Conselho Nacional de Desenvolvimento Científico e Tecnológico (CNPq processo no. 126216/2009-6). The authors thank Espaço da Escrita - Pró-Reitoria de Pesquisa (UNICAMP) for the language services provided.

\section{References}

AL-SHABANAH, O.A., 1993. Inhibition of adriamycin-induced micronuclei by desferrioxamine in Swiss albino mice. Mutation Research Letters, vol. 301, no. 2, pp. 107-111. http://dx.doi. org/10.1016/0165-7992(93)90032-Q. PMid:7678167.

ALVES, J.M., MUNARI, C.C., MONTEIRO NETO, M. A. B., FURTADO, R.A., SENEDESE, J.M., BASTOS, J.K. and TAVARES, D.C., 2013. In vivo protective effect of Copaifera langsdorffii hydroalcoholic extract on micronuclei induction by doxorubicin. Journal of Applied Toxicology, vol. 33, no. 8, pp. 854-860. http://dx.doi.org/10.1002/jat.2777. PMid:22611044.

ANDÚJAR, I., RECIO, M. C., GINER, R. M. and RÍOS, J. L., 2012. Cocoa polyphenols and their potential benefits for human health. Oxidative Medicine and Cellular Longevity, vol. 9, pp. 906252. http://dx.doi.org/10.1155/2012/906252.

BAHARUM, Z., AKIM, A.M., TAUFIQ-YAP, Y.H., HAMID, R.A. and KASRAN, R., 2014. In vitro antioxidant and antiproliferative activities of methanolic plant part extracts of Theobroma cacao. Molecules (Basel, Switzerland), vol. 19, no. 11, pp. 18317-18331. http://dx.doi.org/10.3390/molecules191118317. PMid:25389662.

BATES, N., RAWSON-HARRIS, P. and EDWARDS, N., 2015. Common questions in veterinary toxicology. The Journal of Small Animal Practice, vol. 56, no. 5, pp. 298-306. http://dx.doi. org/10.1111/jsap.12343. PMid:25728477.

BEAN, C.L., ARMSTRONG, M.J. and GALLOWAY, S.M., 1992. Effect of sampling time on chromosome aberration yield for 7 chemicals in Chinese hamster ovary cells. Mutation Research. Fundamental and Molecular Mechanisms of Mutagenesis, vol. 265, no. 1, pp. 31-44. http://dx.doi.org/10.1016/0027-5107(92)900373. PMid:1370241.
BORIOLLO, M.F.G., RESENDE, M.R., SILVA, T.A., PÚBLIO, J.Y., SOUZA, L.S., DIAS, C.T.S., OLIVEIRA, N.M.S. and FIORINI, J.E., 2014a. Evaluation of the mutagenicity and antimutagenicity of Ziziphus joazeiro Mart. bark in the micronucleus assay. Genetics and Molecular Biology, vol. 37, no. 2, pp. 428-438. http://dx.doi. org/10.1590/S1415-47572014000300016. PMid:25071409.

BORIOLLO, M.F.G., SOUZA, L.S., RESENDE, M.R., SILVA, T.A., OLIVEIRA, N.D.M.S., RESCK, M.C.C. and FIORINI, J.E., 2014b. Nongenotoxic effects and a reduction of the DXR-induced genotoxic effects of Helianthus annuus Linné (sunflower) seeds revealed by micronucleus assays in mouse bone marrow. $B M C$ Complementary and Alternative Medicine, vol. 14, no. 1, pp. 121. http://dx.doi.org/10.1186/1472-6882-14-121. PMid:24694203.

BORIOLLO, M.F.G., SILVA, T.A., RODRIGUES-NETTO, M.F., SILVA, J.J., MARQUES, M.B., DIAS, C.T.S., HÖFLING, J.F., RESCK, M.C.C. and OLIVEIRA, N.M.S., 2018. Reduction of doxorubicin-induced genotoxicity by Handroanthus impetiginosus in mouse bone marrow revealed by micronucleus assay. Revista Brasileira de Biologia $=$. Brazilian Journal of Biology $=$ Revista Brasileira de Biologia, vol. 78, no. 1, pp. 1-12. http://dx.doi. org/10.1590/1519-6984.18515. PMid:28699970.

BRUSICK, D., MYHR, B., GALLOWAY, S., RUNDELL, J., JAGANNATH, D. R. and TARKA, S., 1986. Genotoxicity of theobromine in a series of short-term assays. Mutation Research/ Genetic Toxicology, vol. 169, no. 3, pp. 105-114. https://doi. org/10.1016/0165-1218(86)90089-3.

CORTI, R., FLAMMER, A.J., HOLLENBERG, N.K. and LUSCHER, T.F., 2009. Cocoa and cardiovascular health. Circulation, vol. 119, no. 10, pp. 1433-1441. http://dx.doi. org/10.1161/CIRCULATIONAHA.108.827022. PMid:19289648.

DE LA LUZ CÁDIZ-GURREA, M., FERNÁNDEZ DE LAS NIEVES, I., AGUILERA SAEZ, L.M., FERNÁNDEZ-ARROYO, S., LEGEAI-MALLET, L., BOUAZIZ, M. and SEGURACARRETERO, A., 2019. Bioactive compounds from Theobroma cacao: effect of isolation and safety evaluation. Plant Foods for Human Nutrition (Dordrecht, Netherlands), vol. 74, no. 1, pp. 4046. http://dx.doi.org/10.1007/s11130-018-0694-x. PMid:30324543.

DECORDIER, I., DILLEN, L., CUNDARI, E. and KIRSCHVOLDERS, M., 2002. Elimination of micronucleated cells by apoptosis after treatment with inhibitors of microtubules. Mutagenesis, vol. 17, no. 4, pp. 337-344. http://dx.doi.org/10.1093/ mutage/17.4.337. PMid:12110631.

DELVAEYE, M., VEROVSKI, V., DE NEVE, W. and STORME, G., 1993. DNA breakage, cytotoxicity, drug accumulation and retention in two human ovarian tumor cell lines AZ224 and AZ364 treated with adriamycin, modulated by verapamil. Anticancer Research, vol. 13, no. 5A, pp. 1533-1538. PMid:8239532.

DHAWAN, A., KAYANI, M.A., PARRY, J.M., PARRY, E. and ANDERSON, D., 2003. Aneugenic and clastogenic effects of doxorubicin in human lymphocytes. Mutagenesis, vol. 18, no. 6, pp. 487-490. http://dx.doi.org/10.1093/mutage/geg024. PMid:14614182.

DILLINGER, T.L., BARRIGA, P., ESCÁRCEGA, S., JIMENEZ, M., LOWE, D.S. and GRIVETTI, L.E., 2000. Food of the gods: cure for humanity? A cultural history of the medicinal and ritual use of chocolate. The Journal of Nutrition, vol. 130, no. 8S, suppl, pp. 2057S-2072S. http://dx.doi.org/10.1093/jn/130.8.2057S. PMid:10917925.

ENGLER, M.B. and ENGLER, M.M., 2006. The emerging role of flavonoid-rich cocoa and chocolate in cardiovascular health 
and disease. Nutrition Reviews, vol. 64, no. 3, pp. 109-118. http:// dx.doi.org/10.1111/j.1753-4887.2006.tb00194.x. PMid:16572598.

GU, Y., YU, S. and LAMBERT, J.D., 2014. Dietary cocoa ameliorates obesity-related inflammation in high fat-fed mice. European Journal of Nutrition, vol. 53, no. 1, pp. 149-158. http:// dx.doi.org/10.1007/s00394-013-0510-1. PMid:23494741.

GWALTNEY-BRANT, S., HOLDING, J.K., DONALDSON, C.W., EUBIG, P.A. and KHAN, S.A., 2001. Renal failure associated with ingestion of grapes or raisins in dogs. Journal of the American Veterinary Medical Association, vol. 218, no. 10, pp. 1555-1556. PMid:11393362.

HURST, W.J., TARKA JUNIOR, S.M., POWIS, T.G., VALDEZ JUNIOR, F., and HESTER, T.R., 2002. Archaeology: cacao usage by the earliest Maya civilization. Nature, vol. 418, no. 18, pp. 289-290. http://dx.doi.org/10.1038/418289a. PMid:12124611.

INTERNATIONAL COCOA ORGANIZATION - ICCO, 2013. The world cocoa economy: past and present. London: ICCO.

JAGETIA, G.C. and NAYAK, V., 2000. Effect of doxorubicin on cell survival and micronuclei formation in HeLa cells exposed to different doses of gamma-radiation. Strahlentherapie und Onkologie, vol. 176, no. 9, pp. 422-428. http://dx.doi.org/10.1007/ PL00002351. PMid:11050916.

JANG, S., SUN, J., CHEN, P., LAKSHMAN, S., MOLOKIN, A., HARNLY, J.M., VINYARD, B.T., URBAN JUNIOR, J.F., DAVIS, C.D. and SOLANO-AGUILAR, G., 2016. Flavanol-enriched cocoa powder alters the intestinal microbiota, tissue and fluid metabolite profiles, and intestinal gene expression in pigs. The Journal of Nutrition, vol. 146, no. 4, pp. 673-680. http://dx.doi. org/10.3945/jn.115.222968. PMid:26936136.

JOHANSSON, M.A.E., KNIZE, M.G., JAGERSTAD, M. and FELTON, J.S., 1995. Characterization of mutagenic activity in instant hot beverage powders. Environmental and Molecular Mutagenesis, vol. 25, no. 2, pp. 154-161. http://dx.doi.org/10.1002/ em.2850250209. PMid:7698108.

KIM, J., KIM, J., SHIM, J., LEE, C.Y., LEE, K.W. and LEE, H.J., 2014. Cocoa Phytochemicals: Recent Advances in Molecular Mechanisms on Health. Critical Reviews in Food Science and Nutrition, vol. 54, no. 11, pp. 1458-1472. http://dx.doi.org/10.1 080/10408398.2011.641041. PMid:24580540

KIRSCH-VOLDERS, M., SOFUNI, T., AARDEMA, M., ALBERTINI, S., EASTMOND, D., FENECH, M., ISHIDATE, M. Jr., KIRCHNER, S., LORGE, E., MORITA, T., NORPPA, H., SURRALLÉS, J., VANHAUWAERT, A. and WAKATA, A., 2003. Report from the in vitro micronucleus assay working group. Mutation Research/Genetic Toxicology and Environmental Mutagenesis, vol. 540, no. 2, pp. 153-163. http://dx.doi.org/10.1016/j. mrgentox.2003.07.005. PMid:14550499.

MAGISTRELLI, D., ZANCHI, R., MALAGUTTI, L., GALASSI, G., CANZI, E. and ROSI, F., 2016. Effects of cocoa husk feeding on the composition of swine intestinal microbiota. Journal of Agricultural and Food Chemistry, vol. 64, no. 10, pp. 2046-2052. http://dx.doi.org/10.1021/acs.jafc.5b05732. PMid:26877143.

MATEUCA, R., LOMBAERT, N., AKA, P.V., DECORDIER, I. and KIRSCH-VOLDERS, M., 2006. Chromosomal changes: induction, detection methods and applicability in human biomonitoring. Biochimie, vol. 88, no. 11, pp. 1515-1531. http:// dx.doi.org/10.1016/j.biochi.2006.07.004. PMid:16919864.

MURILLO, J.L., VILLA, D.M.G., MARÍN, S.B.A., PÁEZ, F.A.R. and GARTNER, G.A.L., 2011. Caracterización molecular de clones de Theobroma cacao L., por medio de marcadores moleculares microsatélites. Luna Azul, no. 32, pp. 52-60.

OHNO, M., SAKAMOTO, K.Q., ISHIZUKA, M. and FUJTA, S., 2009. Crude cacao Theobroma cacao extract reduces mutagenicity induced by benzo[a]pyrene through inhibition of CYP1A activity in vitro. Phytotherapy Research, vol. 23, no. 8, pp. 1134-1139. http://dx.doi.org/10.1002/ptr.2762. PMid:19170136.

ORGANISATION FOR ECONOMIC CO-OPERATION AND DEVELOPMENT - OECD, 2016. Guideline for the testing of chemicals: mammalian erythrocyte micronucleus test. Paris: OECD, no. 474

OSAKABE, N., YAMAGISHI, M., NATSUME, N., TAKIZAWA, T., NAKAMURA, T., OSAWA, T., 2000. Antioxidative polyphenolic substances in cacao liquor, In: T.H. PARLIMENT, C.-T. HO, P. SCHIEBERLE, eds, Caffeinated beverages: health benefits, physiological effects, and chemistry. Washington: American Chemical Society, pp. 88-101. http://dx.doi.org/10.1021/bk2000-0754.ch011.

PTOLEMY, A.S., TZIOUMIS, E., THOMKE, A., RIFAI, S. and KELLOGG, M., 2010. Quantification of theobromine and caffeine in saliva, plasma and urine via liquid chromatography-tandem mass spectrometry: A single analytical protocol applicable to cocoa intervention studies. Journal of Chromatography. B, Analytical Technologies in the Biomedical and Life Sciences, vol. 878, no. 3-4, pp. 409-416. http://dx.doi.org/10.1016/j.jchromb.2009.12.019. PMid:20045386.

RAMIRO, E., FRANCH, A., CASTELLOTE, C., ANDRÉSLACUEVA, C., IZQUIERDO-PULIDO, M. and CASTELL, M., 2007. Effect of Theobroma cacao flavonoids on immune activation of a lymphoid cell line. British Journal of Nutrition, vol. 93, no. 6, pp. 859-866. http://dx.doi.org/10.1079/BJN20051443. PMid: 16022755

RAMIRO-PUIG, E. and CASTELL, M., 2009. Cocoa: antioxidant and immunomodulator. British Journal of Nutrition, vol. 101, no. 7, pp. 931-940. http://dx.doi.org/10.1017/S0007114508169896. PMid:19126261.

REIS, G.S.M., ALMEIDA, A.A.F., ALMEIDA, N.M., CASTRO, A.V., MANGABEIRA, P.A.O. and PIROVANI, C.P., 2015. Molecular, biochemical and ultrastructural changes induced by $\mathrm{Pb}$ toxicity in seedlings of Theobroma cacao L. PLoS One, vol. 10, no. 7, pp. 1-26. http://dx.doi.org/10.1371/journal.pone.0129696. PMid:26146994.

RENNER, H.W. and MUNZNER, R., 1982. Genotoxicity of cocoa examined by microbial and mammalian systems. Mutation Research Letters, vol. 103, no. 3-6, pp. 275-281. http://dx.doi. org/10.1016/0165-7992(82)90054-9. PMid:7045646.

SCHEWE, T., STEFFEN, Y. and SIES, H., 2008. How do dietary flavanols improve vascular function? A position paper. Archives of Biochemistry and Biophysics, vol. 476, no. 2, pp. 102-106. http://dx.doi.org/10.1016/j.abb.2008.03.004. PMid:18358827.

SOUZA, V.L., ALMEIDA, A.-A.F., SOUZA, J. S., MANGABEIRA, P.A.O., JESUS, R.M., PIROVANI, C.P., AHNERT, D., BALIGAR, V.C. and LOGUERCIO, L.L., 2014. Altered physiology, cell structure, and gene expression of Theobroma cacao seedlings subjected to $\mathrm{Cu}$ toxicity. Environmental Science and Pollution Research International, vol. 21, no. 2, pp. 1217-1230. http://dx.doi. org/10.1007/s11356-013-1983-4. PMid:23888348.

SUGIMOTO, N., MIWA, S., HITOMI, Y., NAKAMURA, H., TSUCHIYA, H. and YACHIE, A., 2014. Theobromine, the Primary Methylxanthine Found in Theobroma cacao, Prevents 
Malignant Glioblastoma Proliferation by Negatively Regulating Phosphodiesterase-4, Extracellular Signal-regulated Kinase, Akt/ mammalian Target of Rapamycin Kinase, and Nuclear Fact. Nutrition and Cancer-an International Journal, vol. 66, no. 3, pp. 419-423. http://dx.doi.org/10.1080/01635581.2013.877497 . PMid:24547961.

SUMMA, C., MCCOURT, J., CÄMMERER, B., FIALA, A., PROBST, M., KUN, S., ANKLAM, E. and WAGNER, K.-H., 2008. Radical scavenging activity, anti-bacterial and mutagenic effects of Cocoa bean Maillard Reaction products with degree of roasting. Molecular Nutrition \& Food Research, vol. 52, no. 3, pp. 342-351. http://dx.doi.org/10.1002/mnfr.200700403. PMid:18293302.

VARELA-LÓPEZ, A., BATTINO, M., NAVARRO-HORTAL, M.D., GIAMPIERI, F., FORBES-HERNÁNDEZ, T.Y., ROMEROMÁRQUEZ, J.M., COLLADO, R. and QUILES, J.L., 2019. An update on the mechanisms related to cell death and toxicity of doxorubicin and the protective role of nutrients. Food and Chemical Toxicology, vol. 29, no. 134, pp. 110834. http://dx.doi. org/10.1016/j.fct.2019.110834. PMid:31577924.

VENKATESH, P., SHANTALA, B., JAGETIA, G.C., RAO, K.K. and BALIGA, M.S., 2007. Modulation of doxorubicin-induced genotoxicity by Aegle marmelos in mouse bone marrow: a micronucleus study. Integrative Cancer Therapies, vol. 6, no. 1, pp. 42-53. http:// dx.doi.org/10.1177/1534735406298302. PMid:17351026.

VINSON, J.A., PROCH, J., BOSE, P., MUCHLER, S., TAFFERA, P., SHUTA, D., SAMMAN, N. and AGBOR, G.A., 2006. Chocolate is a powerful ex vivo and in vivo antioxidant, an antiatherosclerotic agent in an animal model, and a significant contributor to antioxidants in the European and American diets. Journal of Agricultural and Food Chemistry, vol. 54, no. 21, pp. 8071-8076. http://dx.doi.org/10.1021/jf062175j. PMid:17032011.

WEISBURGER, J.H., 2001. Chemopreventive effects of cocoa polyphenols on chronic diseases. Experimental Biology and Medicine, vol. 226, no. 10, pp. 891-897. http://dx.doi. org/10.1177/153537020122601003. PMid:11682694.

WILLIAMSON, G. and MANACH, C., 2005. Bioavailability and bioefficacy of polyphenols in humans. II. Review of 93 intervention studies. The American Journal of Clinical Nutrition, vol. 81, no. 1, suppl. 1, pp. 243S-255S. http://dx.doi.org/10.1093/ ajen/81.1.243S. PMid:15640487.

WOLLGAST, J. and ANKLAM, E., 2000. Review on polyphenols in Theobroma cacao: changes in composition during the manufacture of chocolate and methodology for identification and quantification. Food Research International, vol. 33, no. 6, pp. 423-447. http:// dx.doi.org/10.1016/S0963-9969(00)00068-5.

YAMAGISHI, M., NATSUME, M., NAGAKI, A., ADACHI, T., OSAKABE, N., TAKIZAWA, T., KUMON, H. and OSAWA, T., 2000. Antimutagenic activity of cacao: inhibitory effect of cacao liquor polyphenols on the mutagenic action of heterocyclic amines. Journal of Agricultural and Food Chemistry, vol. 48, no. 10, pp. 5074-5078. http://dx.doi.org/10.1021/jf000050n. PMid:11052780.

YAMAGISHI, M., NATSUME, M., OSAKABE, N., NAKAMURA, H., FURUKAWA, F., IMAZAWA, T. and HIROSE, M., 2002. Effects of cacao liquor proanthocyanidins on PhIP-induced mutagenesis in vitro, and in vivo mammary and pancreatic tumorigenesis in female Sprague-Dawley rats. Cancer Letters, vol. 185, no. 2, pp. 123-130. http://dx.doi.org/10.1016/S0304-3835(02)00276-8. PMid:12169385.

YAMAGISHI, M., OSAKABE, N., NATSUME, M., ADACHI, T., TAKIZAWA, T., KUMON, H. and OSAWA, T., 2001. Anticlastogenic activity of cacao: inhibitory effect of cacao liquor polyphenols against mitomycin C-induced DNA damage. Food and Chemical Toxicology, vol. 39, no. 12, pp. 12791283. http://dx.doi.org/10.1016/S0278-6915(01)00076-X. PMid:11696402. 